\title{
Rio 2016 legacy(?): immediate perceptions
}

http://dx.doi.org/10.11606/1807-5509201700010321

Larissa Rafaela GALATTI*

*Faculdade de

Ciências Aplicadas,

Universidade Estadual

de Campinas, Limeira,

SP, Brasil.

\begin{abstract}
Rio 2016 Games were preceded by controversy and doubts about taking place in Brazil. Despite polemics, its achievement could generate a Momentum, a sense of accomplishment and capability since the opening of the Olympic Games until the end of the Paralympic Games. Just some mouths after Rio 2016, there is not much information to confirm its legacy. Anyway, some initial balance can be done about structural elements (the city of Rio de Janeiro and sports facilities in Brazil) and sportive legacy (results, athletes and coaches). These are the main points of this manuscript, that aim to highlight data and immediate perceptions about a possible legacy of the first Olympic Games in South America. After the event, the suggestion that Sports Science community should pay attention in potentialize diagnostic and applied research, hoping to be one of the main propellers of sports as a right for human development, as well as of best performance of athletes at different levels of practice, as much as coaching educational programs.
\end{abstract}

KeYwords: Olympics; Paralympics; Sport legacy; Coach education; Athlete development.

\section{Introduction}

The 28th Olympic Games ("Rio 2016") happened during 17 days (from August 3rd to 21 th), and gathered more than 10,500 athletes from 206 countries who are in search of the 2012 medals in in 42 modalities. The 32 places of competition in 4 regions of Rio de Janeiro required more than 980 thousand items of sporting equipment and about 200 thousand workers, with about 45 thousand volunteers. Considering local and virtual spectators, it is estimated that more than 1 billion people watched the event ${ }^{1}$. Rio 2016 Paralympic Games used the same facilities and took place from September 7 th to 18 th. Over 4.333 athletes came from 159 countries $^{2}$, which disputed 2,373 medals in 23 modalities. Journalists from 154 countries covered the event, which had an audience of 2 million viewers in locu 3 .

These initial numbers show the range of these two mega events that fascinated viewers and mobilized people around the world, in Brazil and especially in Rio de Janeiro. For its demand, greatness and range, in recent decades, there has been an increasing concern about what kind of legacy Olympic and Paralympic Games (most recently) leaf to sports and the country/city that hosts them. The set of improvements to physical infrastructure that accompany huge events are included in a theoretical structure called "legacy" - a word that has positive connotations in social, economic and physical aspects ${ }^{4}$. MacRurY 5 distinguishes and extends the concept of "legacy" in two perspectives:

- series of concrete structural results (stadiums, and other facilities used or not in the after-game phase);

- perspective of "legacy" as generator of a momentum, or positive capacity within the life of a city that helps to develop more projects, connections and new networks, and puts the Olympic Games and other mega events and their preparations as an integrative force within transformation processes for the city, region and country.

For the International Olympic Committee, "the Olympic legacy is multi-disciplinary and dynamic changing over time - and is affected by a variety of local and global factors"'. Considering the context of the first Olympic Games in South America, in this text I understand legacy as "what remains" due to the Olympics/Paralympics Games. I start with a reflection about what is left for Brazil after Rio 2016, aware that there are limits for trying to identify the consequences of the event to the country so soon, because empirical evidence about the extension of effects of these mega events are still very scarce - which includes cities and 
countries that have hosted the games years $\mathrm{ago}^{7-8}$. Therefore, there is not much information to confirm this legacy as little time has gone by after Rio 2016.
Thus, at this point I will highlight data and immediate perceptions about a legacy of the first Olympic Games in South America. Let start it!

\section{Structural elements: the city and sports facilities in Brazil}

We start with the structural part and Rio de Janeiro itself. Four key points were highlighted in the city's candidature file delivered in 2009: safety, sustainability, transportation and city revitalization. In 2016, the numbers indicated by Matтos and KonCHINSKI ${ }^{9}$ give us some perspective of what was left for the city.

Safety and sustainability were the least considered points. Regarding safety, the main issue was the number of murders in Rio de Janeiro. From January to June 2009, 3,198 people were killed. In 2015 this number decreased to 2,105, which could indicate effectiveness of security actions due to the Olympics date getting closer. However, in the same period in 2016, the index grew back $(2,459$ murders $)$, suggesting that safety-related actions may not have been very effective. In terms of sustainability, the high point of the report was Guanabara Bay, Jacarepaguá and Rodrigo de Freitas lagoons depollution: experts indicate that the last one had some improvement, but on the others, it was almost none. On Guanabara Bay, the work had started, but on Jacarepaguá lagoons, not even the environmental license had been completed?

On the other hand, there are indications of benefits in the transportation and revitalization of the city. Concerning the first item, the construction of three express bus corridors had been finished, the so-called BRTs, and a subway extension. Regarding city revitalization, three highlights: the city port region (Olympic Boulevard), improvements on urban infrastructure of Barra da Tijuca, Deodoro Park and surroundings, the most distant region and most in need of transportation and leisure options in the city ${ }^{9}$. In addition of providing these advances immediately to the ones involved in the Olympic Games, the extension of these benefits to the local population is essential, as well as the cost planning to the budget of Government agencies involved. Therefore, from now on, it is necessary to follow the perenniality or consolidation of the advances, as well as the items not covered.

Considering the whole country, an important structural element regarding the sportive aspect are the training centers (TCs). ANTONELLI ${ }^{10}$ investigated nine of them, focusing on those connected to the plan Brasil Medalhas (Brazil Medals) ${ }^{a}$. It is true that the installation of these TCs is an advance, since these spaces are fundamental to develop High Performance Sports (HPS) ${ }^{11}$. However, in the face of international evaluation parameters of TCs of excellence, there are many deficiencies in these spaces, among which we emphasize: many managers accumulate other functions and lack proper educational background, resulting in an amateur and unprofessional administration; there is a lack of quality equipment compatible with requirements of excellence; only at the Volleyball Center inside the TC facility there is an educational center for athletes who train for a longer period; there is a lack of scientific research and partnerships with universities and research institutions ${ }^{10}$. Concerning Paralympic sports, we point out the Brazilian Paralympic Center, which opened a few days before Rio 2016 and, therefore, little contributed to the training of athletes in this cycle.

As well as advances in Rio de Janeiro, the use, maintenance and management of new spaces for sports must be followed to verify if there is a legacy in terms of "more projects, connections and new networks" from these spaces. Applied research on sports management would be interesting for these spaces, being an opportunity to potentialize this Brazilian sport field still in consolidation. 


\section{Sports, results, athletes and coaches}

Thinking about Olympic and Paralympic legacy just considering results would impoverish the experience, as well as not considering them would empty the meaning of the event. In the Paralympic Games the 5 th position was the goal. We finished on the 8th position, with 14 gold medals - eight less than Australia, the fifth-ranked. Regarding gold medals, the performance was the same had in Athens 2004 performance, worse than in Beijing (16 golds and ninth position overall) and London (21 gold medals and 7 th position overall). However, the total number of 72 medals is unique and historic, since the biggest number of medals so far was the 47 medals in Beijing. Thus, although the performance in number of gold medals and final placement did not fulfill expectations, a qualitative growth of the Paralympic movement is evident in Brazil considering the number of athletes competing at a high level.

In the Olympic games, the Brazilian delegation had its best position of all time in Rio de Janeiro, with the 13th position, with 19 medals: 7 golds, 6 silvers and 6 bronzes. The investments were extremely high to reach this historic position. However, did we really evolve this much? In London 2012, Brazil finished in the 22nd position, with 3 golds, 5 silvers and 9 bronzes. That means in Rio we only won two more medals than in the previous edition, which means the worst improvement of a host country in recent times. In 2000, in the Sydney games, Australia won 17 more medals than in the previous edition; as the host country, Greece won 3 more medals than in the previous Olympic Games. China raised to 37 medals and Great Britain won 18 more medals ${ }^{12}$. However, Brazil has never been in so many finals before, which may indicate more highlevel athletes in Olympic terms for next editions.

But, to think about legacy, it is not possible to focus only on results and isolated medals in an Olympic Edition - the performance during Olympic editions and, especially, policies and high performance sports development programs need to be on the agenda. China and Great Britain are good examples to discuss this issue.

- China was announced as the host country in 2001 and in the Athens 2004 Olympic Games, it won the 2 nd position overall, summing up 63 medals. As the host in 2008, the country won 100 medals and the first position overall. In London 2012, China got the second position with 88 medals. In Rio de Janeiro, the third position with 70 medals ${ }^{13}$.
- Great Britain had London chosen as the host city in 2005. In the 2008 Olympic Games, it won 47 medals and reached the 4th position. The country got the third position as the host in 2012 and obtained 65 medals. In Rio 2016, it finished at the second position ( 67 medals) - the results were also better in the Paralympic Games.

By observing China and Great Britain since 2008, we have two perspectives: regarding the limit of considering only the behavior of final results, we can notice China's focus on demonstrating a spectacular performance in its host edition, since there was an increase before and a decrease after Beijing 2008. Great Britain had been growing before London 2012 and even had a better result in Rio de Janeiro, which may suggest improvements in the organization of the country's Olympic sport as a legacy associated with London 2012.

Between the two countries, Great Britain is the one that shows a growth in stability. Its performance in Rio is associated with many factors and seems to be connected with the fact that it received, in 2005, the right to host the Olympic and Paralympic Games. Several actions focused on sports (Olympic games, in particular) begin during this period: 1) lottery money invested in sports, generating a large volume of financial resources; 2) supporting policy for modalities with greater chances of winning medals (such as cycling, sailing and equestrianism, which not by coincidence have a strong tradition and cultural identity with Great Britain); 3) high performance training system strongly supported by science and technology; 4) constant renewal of great athletes by a system that encourages young talents to develop, rather than a policy of applying resources in a few young athletes with potential; 5) several actions to create a sense of belonging to the "Team Great Britain", with the culture of victory by interacting with experienced and successful athletes - which was possible after reducing the conflicts between two central institutions in the British HPS: UK Sports and British Olympics, which started to delimit responsibilities and actions ${ }^{14-15}$.

But let's get back to Brazil. By observing the country numbers in the 2016 Olympic and Paralympic Games, it is possible to expect good results in Tokyo 2020: the country had never achieved so many finals in so many modalities before as in Rio de Janeiro, indicating that if the country keeps investing and giving competition opportunities 
for the athletes, the results may continue to evolve. However, let us better understand HPS in Brazil.

These mega events required investments in infrastructure for high performance sports, as in the already mentioned High Performance Centers and complex Olympic competition spaces in Rio de Janeiro ${ }^{16}$. Also it would be expected investment in coaches, athletes and other necessary human and material resources, in addition to managers with the ability to make it work ${ }^{17-18}$. However, it seems that the development of human resources was not the destination focus of resources and this may compromise a sustainable evolution of the Brazilian Olympic and Paralympic sports: after all, if the bet was distributing a lot of financial resources without ensuring development of new human resources with consistent knowledge and learning support considering the Rio 2016 experience, if there is a privation of resources for HPS, there might be a retrocession in the initial achievements regarding results of this Olympic cycle - moreover, watching the unstable political and economic scenario of the country, this is a quite pertinent fear.

In a comparative analysis carried out by the SPLISS network (Sports Policy Factors Leading to International Sporting Success), besides Brazil, other 14 countries have been investigated, including Great Britain and Japan, former host and next host of the Olympic and Paralympic Games. Among them, Brazil is one of the countries receiving the highest financial investment in HPS, but a clear coordination of actions for sport management and its resources has not been identified. Among the nine main points investigated, the country surpasses the average of nations investigated in only two of them: "financial support" and "participation and organization of (inter) national competitions," showing that at least in recent years, investments and competitions were abundant. However, HPS weaknesses in Brazil are "sports facilities" (training ones in particular, as evidenced by the study of ANTONELLI ${ }^{10}$, and main points related to development of young athletes and coaches; in addition to them, there is Brazil low score regarding career and post-career of athletes and participation sports ${ }^{\mathrm{b}}$. This panorama reveals little care with the main characters: participants, athletes (including young people) and coaches.

Starting with these indicatives, in this period after big events in Brazil, the absence of spaces for starting in sports is an alert: coaches and managers have noticed an immediate increase of children and young people looking for different sports due to Rio 2016 Olympic Games, as reported in Santa Catarina $^{19}$, Amazonas ${ }^{20}$ and São Paulo ${ }^{21}$. However, this may not reflect an increase in number of practitioners, especially due to absence of places to practice and develop in a sport, which is related to the absence of effective public policies on participation sports and education ${ }^{22-23}$. Now is time to look at new scenarios and their potential for sports promotion, such as NGOs, which used to be seen as exclusive spaces for educational or participation sports. Nowadays, they can also be observed as part of the development course of HPS athletes. MAGRI et al. ${ }^{24}$ observed that $7 \%$ of athletes involved in Novo Basquete Brasil (New Basketball Brazil) had their first systematic practice in basketball in NGOs. This number rises to $14 \%$ among athletes of Liga de Desenvolvimento de Basquete (LDB - Basketball Development League), with athletes up to 23 years old. In the Rio 2016 games, three cases of athletes trained in NGOs catches the attention: Rafaela Silva, Judo Olympic champion, had her initiation, training and development as an HPS athlete in an NGO called "Instituto Reação"; Isaquias Queiroz, the first Brazilian to win 3 medals in a single edition of the Olympic Games, had his sports training in a social project, as well as the Taekwondo bronze medalist Maicon Andrade. To be successful, the development process of athletes and practitioners requires intense connection between governmental and non-governmental agencies to promote sports, which seems not to happen in Brazil. In addition to limitations, there are difficulties to maintain these children and young people in sports, a fundamental element in long-term education processes of HPS athletes ${ }^{25}$.

I dare saying this is one of the biggest negligence regarding the Olympic Games in Brazil: few initiatives to extend access and permanence in sports during life - such initiatives existed, however, considering a 200-millin people country, of which about 40 million are under 14 years old, little was done by isolated initiatives of individuals and institutions, rather than systematic or political sport actions for the people. We will have to wait a few years to verify whether or not there was an increase of places for systematized sports practice, as well as in number of sportspeople, whether in participation or high performance sports. Fewer people into the dynamics of the sports practice not only means they are less likely to become Olympic athletes, but I think that, above all, that means fewer people having the opportunity to develop themselves in 
sports, to enjoy the phenomenon and to live it as a practitioner or spectator, which weakens the social value of Olympic and Paralympic sport.

Still regarding human resources, the sports coach is a central character in the process, the main responsible for the organization, systematization, application and evaluation of pedagogical procedures inside and outside the space of practice/competition for the athlete's development ${ }^{26}$. In Brazil, the sports coach is regulated as a profession and must have a degree in Physical Education to act - except for football - in a previously regulated profession ${ }^{27-28}$. Thus, for most sports, since 1998 coaches must have a higher education degree, which includes an initial education in the area. If on the one hand initial education of coaches is an advance, on the other, there are challenges to be overcome, such as curriculum and science around sports coaches.

A first challenge is Physical Education curricula, which are generalists and suitable for the education of participation coaches. However, current proposals are insufficient for the background of HPS coaches ${ }^{29}$. Specifically in HPS, offer of coaches in the country seems to be insufficient. At least, national confederations have constantly been choosing foreign coaches for national teams. The example of collective modalities is emblematic: among the fourteen coaches of male and female Brazilian teams, seven were foreigners. This shows that national confederations do not perceive national coaches as competent to lead teams in the biggest competition of the calendar of each modality. Another alarming aspect is the total absence of female coaches in this group: not even one! Therefore, Rio 2016 seems to have not stimulated coaches' education programs before the event - will this come as legacy?

In addition, despite being a higher education profession, universities (where research is focused in Brazil), little is published on national magazines about coaches: there were 82 articles in national scientific journals between 2000 and 2015 . Although growing in recent years, we know little and propose even less about education and development of sports coaches, the key agents on training of athletes and practitioners, since they are central potentiators of the sport phenomenon in its multiple possibilities ${ }^{30-31}$. Therefore, we must think how to develop coaches throughout their careers, at different levels of performance.

National confederations and state federations are the basic organizations in this process, which do not assume enough their roles of educators of sportspeople. In Brazil, do these institutions offer guidelines for developing athletes? What about coaches' education? Up to the beginning of this year, among the 30 national confederations of the Olympic summer and winter modalities, 12 of them (less than half) offered some type of education, in addition to the Brazilian Olympic Committee (BOC) program ${ }^{31}$; with an insufficient number and without a guiding structure for these courses. Milistetd et al. ${ }^{31}$ indicate that the same few people benefit from coaches experience and tend to be more traditional, focusing on professional content, without offering much support regarding interpersonal and intrapersonal knowledge of coaches, defended in more recent literature as differentials in their interventions ${ }^{32}$. If the legacy is poor at this point, the need for action is urgent.

Therefore, we verify that we have new sports facilities and new HPS athletes capable of high performance in the Olympic and Paralympic Games (perhaps less than expected, but more than we ever had). However, there is a lack of organization and management of HPS and people involved with this sporting manifestation in Brazil. Despite Olympic and Paralympic Games and other events that came to the country - World Cup, Pan American Games, Military World Games and many other international events - structure does not seem to have solidified so that a robust legacy can already be identified.

\section{Thinking of perspectives}

Some points must be considered, which could be taken as thoughts for a guideline design for this next Olympic cycle:

- financial and political instability in the country may result in lower financial resources, with decrease of state and private investment in sports. This factor may mean a lower international interchange, and less participation opportunities in competitions, as well as a low hiring of foreign human resources;

We have observed at the current moment that there is a below-average investment in HPS human factors: career planning and support for development 
of athletes and coaches is poor in the country. This point should be central in a governmental sports policy, as well as inside BOC, confederations, federations and other sports organizations;

- the third alarming element is the low investment in sport in our country, in addition to the absence of a connected structure for management of different levels of sports offer.

- physical legacy - especially improvements provided for Rio de Janeiro city and sports facilities in the country - is not assured: it is necessary to monitor how and who will have access to these spaces.

- human legacy: in addition to HPS, which is going to be the sports offer for people regarding basic and participation sports? Maintenance and management of human resources in order to expand reach of sports in the country from Rio 2016 milestone are fundamental so that a legacy - what remains for Brazilian people - in fact happen. The country's sporting culture is still limited. Besides, actions to better appreciate and practice sports as a phenomenon in its multiple possibilities, does not seem to have been the strength of the Olympic Games in Brazil.

Rio 2016 Games were preceded by controversy and doubts about taking place in Brazil by Brazilians as well as by the international community. Despite polemics, its achievement was able to generate a Momentum, a sense of accomplishment and capability which since the opening of the Olympic Games until the end of the Paralympic Games, mobilized and affectionately amazed many Brazilians and sports appreciators around the world. From 2016 on, Rio de Janeiro will be forever an Olympic city and Brazil, the first South American country to receive the event. However, legacy is not the moment, but what remains from it and what is built with the driven sentiment. There is much to be done. We, scientists linked to Sports Science and Physical Education, can start by potentializing diagnostic and applied research, hoping to be one of the main propellers of sports as a right for human development, as well as of best performance of athletes at different levels of practice.

\section{Notes}

a. The following centers have been investigated: Brazilian Volleyball Development Center (CDV) in Saquarema (RJ); Pan American Judo Center, in Lauro de Freitas (BA); Boxing Training Center, in Santo Amaro (SP); High Performance Center (NAR), in Santo Amaro (SP); Brazil Team Training Center (Martial Arts/Swimming/Judo), in Deodoro (RJ); Athletics Center (Arena Caixa), in São Bernardo (SP); Canoe Slalom Training Center in Foz do Iguaçu (PR); Center for Handball Development in São Bernardo (SP); Artistic Gymnastics Center in São Bernardo (SP).

b. Information submitted by a SPLISS team through a mailing list, under the title "How did the 15 SPLISS 2.0 nations do in Rio?," received on August 31th, 2016. 


\section{Resumo}

Legado Rio 2016 (?): percepções imediatas

Os Jogos Olímpicos Rio 2016 foram precedidos por controvérsias e dúvidas sobre sua realização no Brasil. Apesar das polêmicas, sua realização foi capaz de gerar um Momentum, um sentimento de orgulho e capacidade que teve início na abertura dos Jogos Olímpicos e se estendeu até o encerramento dos Jogos Paralímpicos. Apenas alguns meses após o evento, há pouca informação que permita assegurar que há um legado olímpico. No entanto, é possivel arriscar uma análise inicial tendo em consideração aspectos positivos e negativos de elementos estruturais (relacionados à cidade do Rio de Janeiro e instalações esportivas no Brasil) e legado esportivo (resultados, desenvolvimento de atletas e treinadores). Estes são os pontos centrais deste texto, que objetiva destacar dados e percepções iniciais sobre um possível legado dos primeiros Jogos Olímpicos na América do Sul. Pós evento, a sugestão é que a comunidade ligada às Ciências do Esporte foque esforços em potencializar pesquisas diagnósticas e aplicadas, na expectativa de ser um dos pilares propulsores do esporte como direito para o desenvolvimento humano, assim como da melhor performance e desempenho de atletas e treinadores nos diferentes niveis de prática.

Palavras-chave: Jogos Olimpicos; Jogos Paralímpicos; Legado esportivo; Treinador esportivo; Desenvolvimento de atletas.

\section{References}

1. Brasil. Governo Federal. Portal oficial sobre os Jogos Olímpicos e Paralímpicos de 2016. Os números impressionantes dos Jogos Olímpicos Rio 2016. Brasília: Governo Federal; 2016 [cited 2016 Nov 27]. Available from: www.brasil2016. gov.br/pt-br/videos/os-numeros-impressionantes-dos-jogos-olimpicos.

2. International Paralympic Committee. Rio 2016 in numbers; 2016 [cited 2017 May 23]. Avaiable from: https://www. paralympic.org/news/rio-2016-numbers.

3. Brasil. Governo Federal. Portal Brasil. Confira os principais números dos jogos Paralímpicos.Brasília: Governo Federal; 2016 [cited 2016 Nov 27]. Available from: www.brasil.gov.br/esporte/2016/09/info-paralimpiadas.jpg/view.

4. Gaffney C. Mega-events and socio-spatial dynamics in Rio de Janeiro, 1919-2016. J Latin Am Geog. 2016;9:7-29.

5. MacRury I. Regeneração social e cultural. In: DaCosta L, Rizzuti E, Villano B, Miragaya A, editores. Legados de megaeventos esportivos. Brasília: Ministério do Esporte: 2008. p. 153-60.

6. Moragas MD, Kennett C, Puig N. The legacy of the Olympic Games: 1984-2000. Lausanne: IOC; 2003.

7. Horne J, Manzenreiter W. An introduction to the sociology of sports mega-events1. Sociol Rev. 2006;54:1-24.

8. Bechara M. Modelo M4 para gestão de legados de megaeventos esportivos com foco na responsabilidade social e políticas públicas. In: DaCosta L, Rizzuti E, Villano B, Miragaya A, editores. Legados de megaeventos esportivos. Brasília: Ministério do Esporte; 2008. p. 249-64.

9. Mattos R, Konchinski V. Legado olímpico: transporte supera meta; meio ambiente e segurança falham. São Paulo: Grupo Folha; 2016 [cited 2016 Sept 10]. Available from: www.olimpiadas.uol.com.br/noticias/redacao/2016/08/04/ olimpiada-muda-transporte-do-rio-mas-nao-resolve-ambiente-e-de-seguranca.html.

10. Antonelli M. Diagnóstico dos centros de treinamento de alto rendimento do Brasil cujas modalidades atendidas têm expectativa de conquista de medalhas nos Jogos Olímpicos de 2016. Campinas (SP): Universidade Estadual de Campinas, Faculdade de Educação Física; 2016.

11. Mazzei LC, Amaral CMS. Pilar 6: instalaçôes esportivas. In: Böhme MTS, Bastos FC, editores. Relatório de pesquisas em estados e capitais brasileiros. São Paulo: Phorte; 2015. p. 112-28.

12. Folha de S. Paulo. Brasil aproveita muito pouco o fator casa nos jogos do Rio. São Paulo: Grupo Folha; 2016 [cited 2017 Feb 2]. Available from: http://www1.folha.uol.com.br/esporte/olimpiada-no-rio/2016/08/1805573-brasil-aproveita-muito-pouco-o-fator-casa-nos-jogos-do-rio.shtml.

13. Folha de S. Paulo. Quadro de medalhas. São Paulo: Grupo Folha; 2016 [cited 2016 Dec 3]. Available from: www. olimpiadas.uol.com.br/quadro-de-medalhas/. 
14. Gibson O. Team GB's olympic success: five factors behind their Rio medal rush. The Guardian, London, 2016 Aug 15 [cited 2016 Oct 3]. Available from: www.theguardian.com/sport/blog/2016/aug/15/five-factors-team-gb-olympic-success-medal-rush.

15. Fordyce T. Rio Olympic 2016: how did team GB make history? BBC Sport, London, 2016 Aug 22 [cited 2016 Oct 3]. Available from: http://www.bbc.com/sport/olympics/37150155.

16. De Bosscher V, De Knop P, Van Bottenburg M, Shibli S. A conceptual framework for analysing sports policy factors leading to international sporting success. Eur Sport Manag Quart. 2006;6:185-215.

17. Almeida BS, Júnior WM. Comitê Olímpico Brasileiro e o financiamento das Confederações Brasileiras. Rev Bras Ciênc Esporte. 2011;33:163-79.

18. Mazzei LC, Meira TB, Bastos FC, Böhme MTS, De Bosscher V. High performance sport in Brazil. Gest Polít Públ. 2015;24:83-111.

19. Golembiewski B, Vieira F. Jogos Olímpicos faz crescer a procura por esportes na região. Prefixo, Itajaí; 2016 [cited 2016 Nov 18]. Available from: www.agenciaprefixo.com/2016/09/06/jogos-olimpicos-faz-crescer-procura-por-esportes-na-regiao.

20. Portal do Marcos Santos [Internet]. Procura por prática esportiva na Vila Olímpica aumenta em até 50\% após Olimpíadas. 2016 Sept 8 [cited 2016 Nov 18]. Available from: www.portaldomarcossantos.com.br/2016/09/08/procura/.

21. Kurazumi A. Após Rio 2016, aumenta a procura por esportes olímpicos no ABCD. ABCD Maior, São Bernardo, 2016 Sept 2 [cited 2016 Nov 18]. Available from: www.abcdmaior.com.br/materias/esportes/apos-rio-2016-aumenta-a-procura-por-esportes-olimpicos-no-abcd.

22. Bueno L. Políticas públicas do esporte no Brasil: razóes para o predomínio do alto rendimento. São Paulo (SP): Fundação Getúlio Vargas; 2008.

23. Dantas LETPB. Pilar 3: Participaçáo e esporte de base. In: Böhme MTS, Bastos FC, editores. Relatório de pesquisas em estados e capitais brasileiros São Paulo: Phorte; 2015. p. 56-76.

24. Magri A, et al. Local de início de prática do basquetebol: existem diferenças entre atletas da NBB e da LBD? V Congresso Internacional de Jogos Desportivos; 2015; Belo Horizonte, BR. Belo Horizonte: UFMG; 2015. p. 508-12.

25. Bojikian LPB. Pilar 4: identificação e desenvolvimento de talentos esportivos. In: Böhme MTS, Bastos FC, editores. Relatório de pesquisas em estados e capitais brasileiros São Paulo: Phorte; 2015. p. 77-96.

26. Galatti LR, Reverdito RS, Scaglia AJ, Paes RR, Seoane AM. Pedagogia do esporte: tensão na ciência e o ensino dos jogos esportivos coletivos. J Phys Educ. 2014;25:153-62.

27. Brasil. Lei n. 9.696 de 1 de setembro de 1998. Dispóe sobre a regulamentação da Profissão de Educação Física e cria os respectivos Conselho Federal e Conselhos Regionais de Educação Física. Diário Oficial da União, Brasília (1998 Sept 9); Sec. 1:1.

28. Brasil. Lei n. 8.650 de 22 de abril de 1993. Dispóe sobre as relaçóes de trabalho do Treinador Profissional de Futebol e dá outras providências. Diário Oficial da União, Brasília (1993 Apr 23); Sec. 1:5265.

29. Milistetd M, Trudel P, Mesquita I, Nascimento JV. Coaching and coach education in Brazil. Int Sport Coach J. 2014;1:165-72.

30. Galatti L, Bettega OB, Brasil VZ, et al. Coaching in Brazil sport coaching as a profession in Brazil: an analysis of the coaching literature in Brazil from 2000-2015. Int Sport Coach J. 2016;3:316-31.

31. Milistetd M, Ciampolini V, Salles WDN, Ramos V, Galatti LR, Nascimento JV. Coaches' development in Brazil: structure of sports organizational programmes. Sports Coach Rev. 2016;5:138-52.

32. Côté J, Gilbert W. An integrative definition of coaching effectiveness and expertise. Int J Sports Sci Coach. 2009;4:307-23.

\section{Acknowledgements}

The author thanks Espaço da Escrita - Coordenadoria Geral da Universidade - UNICAMP - for the language services provided. 


\begin{tabular}{r|r} 
ADDRESS & \\
Larissa Rafaela Galatti & Submitted: $31 / 01 / 2017$ \\
Faculdade de Ciências Aplicadas & Accepted: 11/02/2017 \\
Universidade Estadual de Campinas & \\
R. Pedro Zaccaria, 1300 - Caixa Postal 1068 & \\
13484-350 - Campinas - SP - BRASIL & \\
e-mail: larissa.galatti@fca.unicamp.br &
\end{tabular}

